\title{
Joseph-Louis Lagrange: essential timeline
}

\section{Sandro Caparrini}

Published online: 6 June 2014

(C) Centro P.RI.ST.EM, Università Commerciale Luigi Bocconi 2014
Abstract A timeline of the life and work of Lagrange.
Keywords Lagrange - Eighteenth century mathematics .
Scientific biography

11736

25 January: born in Turin, at no. 29 of what is today Via Lagrange, firstborn of eleven children. His father, Giuseppe Francesco Lodovico, a doctor in jurisprudence from the University of Turin, is treasurer of the Reale Intendenza delle Fabbriche e Fortificazioni; his mother, Teresa Gros, is the only daughter of a wealthy physician of Cambiano (Piedmont). In the birth registry, his name is given as Giuseppe Lodovico Lagrangia; in letters he generally signed his name De La Grange. In his early years he was educated privately.

\section{0}

Enrolls in the University of Turin, where he devotes himself to the study of law. In the meantime he begins to frequent the university library to further his preferred studies in mathematics. He reads works by Wolf, Newton, Agnesi, d'Alembert and Euler. He attends the lessons in physics given by Giambattista Beccaria and those in mathematics by Filippo Antonio Revelli.

S. Caparrini $(\bowtie)$

Dipartimento di Matematica, Università di Torino, Via Carlo Alberto, 10, 10123 Turin, Italy

e-mail: sandro.caparrini@unito.it

\section{4}

13 July: writes to Giulio Carlo da Fagnano, a mathematician from Pesaro, a letter in which he develops the analogy between the binomial formula and higher-order differentials of the product of two functions.

23 July: publishes his first work, the Lettera di Luigi de La Grange Tournier torinese all'illustrissimo signor conte Giulio Carlo da Fagnano.

Reads Euler's Methodus inveniendi (1744), the first attempt at a systematic treatment of variational problems.

\section{$4 \mathbf{1 7 5 5}$}

12 August: writes to Euler of his own analytical methods for solving variational problems, which would later be known as the calculus of variations.

6 September: Euler replies, warmly praising his method. 26 September: is named assistant for the course in mathematics at the Royal School of Artillery in Turin.

\section{6}

5 October: is elected a corresponding member of the Royal Academy of Sciences and Letters of Berlin.

\section{7}

Together with the chemist G. A. Saluzzo di Monesiglio and the physician G. F. Cigna, he founds a "Private Society" with the aim of promoting research in the fields of the mathematical and natural sciences. 


\section{8}

First epistolary contact with d'Alembert.

\section{9}

Publication of the first volume of the Miscellanea philosophico-mathematica societatis privatae Taurinensis, containing three memoirs by Lagrange, including the "Recherches sur la nature et la propagation du son" in which he takes a position in the dispute about vibrating strings.

\section{2}

Publication of the second volume of the Miscellanea (1760-1761). This contains the "Essai d'une nouvelle méthode pour déterminer les maxima et les minima des formules intégrales indéfinies", where he expounds his own calculus of variations, and the "Application de la méthode précédente à la solution de différents Problèmes de Dynamique", in which he generalizes the principle of least action of Maupertuis and Euler.

\section{3}

November: leaves Turin for the first time for a trip through Europe. He was supposed to arrive to London, but was obliged to interrupt his travels because of illness. His stay in Paris is rich in meetings and experiences: among others, he meets the mathematicians Clauraut, d'Alembert, Fontaine and Condorcet, and sees again the physicist Nollet, who he had met previously in Turin.

\section{4}

May: returns to Turin after stopping briefly in Ferney to meet Voltaire.

He is awarded the prize of the Paris Academy of Sciences for his "Recherches sur la libration de la Lune" (published in 1777). Over the course of his career, Lagrange would win this prize five times.

\section{6}

In the "Recherches sur les inégalités des satellites de Jupiter causées par leur attraction mutuelle", he examines the $n$-body problem.
In Berlin, Euler leaves his position as director of the Class of Mathematics of the Academy and returns to St. Petersburg. D'Alembert takes advantage of the situation to recommend Lagrange to the king of Prussia, Frederick II. 21 August: leaves Turin for Berlin, passing through Paris (where he again meets d'Alembert), London and Hamburg. He arrives in Berlin on 27 October.

6 November: is installed in the Berlin Academy of Sciences as director of the Class of Mathematics.

\section{7}

September: marries his cousin Vittoria Conti (1747-1783).

\section{0}

Publishes in the Proceedings of the Berlin Academy the "Réflexions sur la résolution algébrique des équations", which mark the beginning of modern studies on the resolution of algebraic equations.

\section{2}

20 May: is elected foreign member of the Paris Academy of Sciences.

\section{3}

4 August: death of his wife. 18 September: death of Euler. 29 October: death of D'Alembert.

\section{6}

Following the death of Frederick II (17 August), some changes made at the Academy induce Lagrange to fear for his future in Berlin. Count Mirabeau, on a diplomatic mission to Berlin, convinces him to move to Paris.

\section{7}

18 May: leaves Berlin.

13 June: first time that Lagrange's presence is recorded at the Paris Academy of Sciences.

29 July: becomes a pensionnaire vétéran of the Academy, a title that permits him to take part in all votes. 


\section{8}

12 January: is nominated director of the Paris Academy for 1788.

5 April: presents to the Academy a copy of the Méchanique analitique, just published in Paris but written during his Berlin period.

\section{9}

4 July: is part of a delegation to congratulate the astronomer Bailly for his role as president of the National Assembly.

\section{0}

27 October: together with Laplace, Borda, Condorcet and Tillet, is called to be part of of the Commission on Weights and Measures.

\section{1}

November: is nominated a member of the Bureau de Consultation des arts et des métiers.

\section{2}

March: for some months is one of three administrateurs de la Monnaie.

31 May: marries Renée-Françoise-Adélaide Le Monnier (1767-1833), daughter of the astronomer Pierre Charles and niece of Guillaume, protomedicus to the king.

\section{3}

8 August: the Convention orders the suppression of all academies, and in particular of the Academy of Sciences. Lagrange thus loses his annuity.

6 September: the Convention orders the arrest of all citizens of countries at war with France. An exception is made for Lagrange thanks to his skill in ballistic calculations.

\section{4}

17 January: together with Berthollet, is named a member of the Commission for Public Education.

9 November: is named professor at the École Normale.

\section{5}

24 May: holds his first lesson at the École centrale des Travaux publics (which would later become the École Polytechnique).

Publishes the Cinq leçons données à l'Ecole normale de l'an III, regarding questions of elementary mathematics.

25 June: is named, with Laplace, a member of the Bureau des longitudes (which takes the place of the suppressed Observatory).

27 December: is elected president of the Class of Mathematical and Physical Sciences of the National Institute of Sciences and Arts (which substitutes the former Academy of Sciences).

\section{7}

Publishes the Théorie des fonctions analytiques, based on his lessons at the École Centrale des Travaux Publiques, in which he sets forth his own view of the foundations of infinitesimal calculus.

\section{8}

Publishes the treatise De la résolution des équations numériques de tous les degrés, a reprint of two memoirs from the Berlin period, augmented with notes and comments. December: in Turin, on Talleyrand's orders, the government representative M. A. Eymar and various local authorities pay a formal visit to Lagrange's aged father to reassure him of the new government's keen interest in his family.

24 December: is named senator at the behest of Napoleon.

\section{1}

Publishes the Leçons sur le calcul des fonctions, a complement to the Théorie des fonctions analytiques.

\section{3}

2 October: together with Berthollet, Laplace and Monge, is named a member of the Legion of Honor.

\section{4}

14 June: is promoted to the rank of Grand Official of the Legion of Honor. 


\section{5}

2 September: is a speaker of the commission that proposes a return to the Gregorian calendar.

\section{8}

24 April: is named a Count of the Empire.

\section{1}

Publishes the first volume of the second edition of his treatise on analytical mechanics, which is now entitled Mécanique analytique.

\section{3}

3 April: is conferred to the Imperial Order of the Reunion. 8 April: Monge, Lacépède (president of the Senate) and Chaptal pay him a visit and hear his final reflections.

10 April: dies in his Paris home, in Rue du Faubourg SaintHonoré. He is interred in the Panthéon.

\section{5}

The second volume of the Mécanique analytique is published posthumously.

(Translated from the Italian by Kim Williams)

\section{References}

1. Burzio, F.: Lagrange. UTET, Turin (2013)
2. Itard, J., Lagrange, JL.: 1736-1813. In: Rashed, R. (ed.).Essais d'histoire des mathématiques, pp. 309-334 Blanchard, Paris (1984)

3. Pepe, L., Borgato, M.T.: Lagrange: appunti per una biografia scientifica. La Rosa, Turin (1990)

4. Pepe, L., Lagrange, J.L., Giuseppe, L.: Dizionario Biografico degli Italian, pp. 75-80. Istituto della Enciclopedia italiana, Rome (2004)

5. Taton, R.: Inventaire chronologique de l'oeuvre de Lagrange. Revue d'histoire des sciences 27, 3-36 (1974)

6. Taton, R.: Les débuts de la carrière mathématique de Lagrange: la période turinoise (1736-1766). Symposia mathematica 27, 123-145 (1986)

7. Taton, R.: Sur quelques pièces de la correspondance de Lagrange pour les années 1756-1758. Bollettino di storia delle scienze matematiche 8, 3-19 (1988)

8. Taton, R.: Le départ de Lagrange de Berlin et son installation à Paris en 1787. Revue d'histoire des sciences 41, 39-74 (1988)

9. Taton, R. Lagrange, JL et al.: Révolution française (juillet 1789 novembre 1795). Atti dell'Accademia delle Scienze di Torino, Classe di Scienze Fisiche, Matematiche, Naturali 126, Supplemento La 'Mécanique analytique' de Lagrange et son héritage, vol. 2, pp. 215-255 (1992)

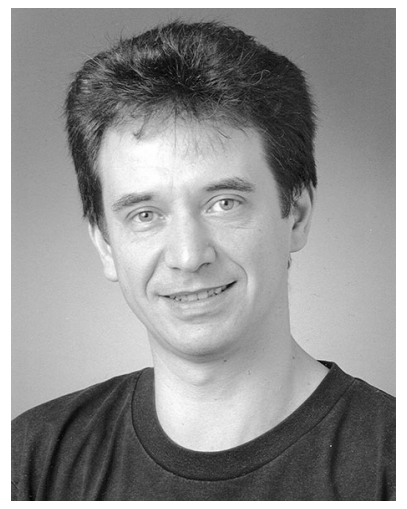

\begin{abstract}
Sandro Caparrini holds degrees in Physics and in Mathematics and a Ph.D. in Mathematics from the University of Turin. His research interests are mainly focused on the history of the interaction between mathematics and mechanics from 1750 onward. He has held postdoctoral positions at the Dibner Institute (Harvard and MIT), at the Cohn Institute (Tel Aviv), at the Institute for the History and Philosophy of Science and
\end{abstract} Technology (Toronto) and at the Dept. of Mathematics of the University of Lille (France). In 2004 he was awarded the Slade Prize from the British Society for the History of Science. 